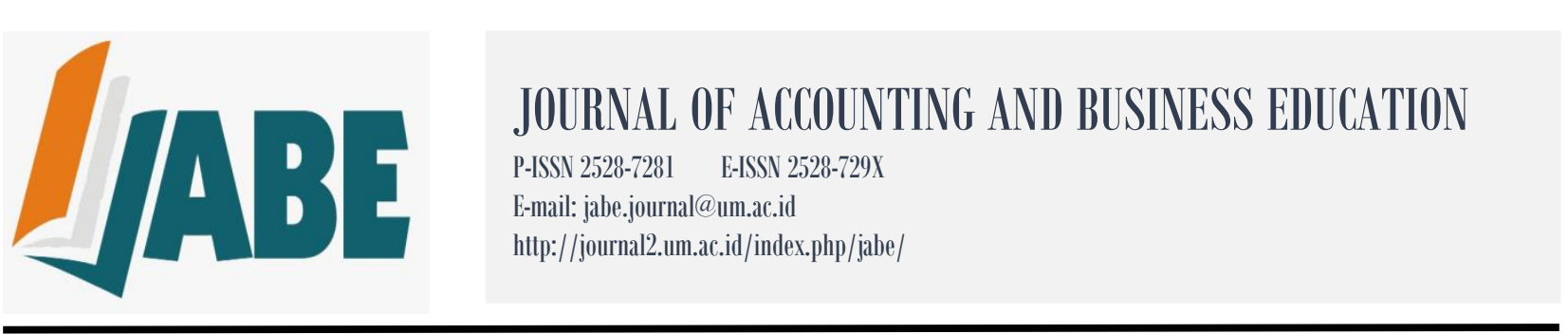

\title{
The Factors Influencing Perceived Ease of Use of E-Learning by Accounting Lecturer
}

\author{
Nujmatul Laily ${ }^{1}$ \\ Fenty Shintya Riadani ${ }^{2}$ \\ ${ }^{1,2}$ Accounting Department, Faculty of Economic, Universitas Negeri Malang, Indonesia \\ email: nujmatul.laily.fe@um.ac.id
}

DOI: http://dx.doi.org/10.26675/jabe.v3i2.8166

\begin{abstract}
This research aims at analyzing the influence of one's anxiety in using computer (computer anxiety), age and gender on perceived ease of use of e-learning by accounting lecturers through their self-efficacy in using computer (computer self-efficacy). The population used in this research is all 34 lecturers at accounting department in X University and the sample is taken using saturated sampling technique since the number of respondents is limited. The data are collected by distributing questionnaire to lecturers. The hypotheses are tested using path analysis test. The research results indicate that: (1) Computer anxiety has insignificant influence on perceived ease of use through computer self-efficacy. (2) Respondent's age has insignificant influence on perceived ease of use through computer self-efficacy. (3) Respondent's gender has insignificant influence on perceived ease of use through computer self-efficacy.
\end{abstract}

Keywords: Computer Anxiety, Age, Gender, Computer Self-Efficacy, Perceived Ease of Use of E-Learning

\section{INTRODUCTION}

- The performance of regional government administration related to the accountability of state finan As time goes, the use of internet for education in Indonesia keeps on developing. This use of internet in education field is commonly known as e-learning. E-learning is a teaching and learning process which employs computer, network, teaching software equipped with such facilities as communication, monitoring and evaluation. Using e-learning, the meeting between lecturers and students is not necessarily made face to face. X University is one of state universities in Indonesia that begins to apply e-learning in its teaching and learning process. X University's E- learning was built by its ICT Center in 2008. This ICT Center is a working unit which processes data and information in academic and administrative fields under the responsibility of and should report to the Rector.

Despite the great advantages offered by e-learning, this system attracts less interest and is infrequently used by both lecturers and students. In the university, even until now some lecturers and students have not used e-learning as expected by TIK as its administrator. Based on the researcher's experience during her study at X University, only several lecturers have employed e-learning service. This is supported by the interview with a lecturer as one of the administrators of e-learning at $\mathrm{X}$ University. He said that currently at X University only three lecturer actually utilized e-learning 
service actively in the form of Moodle which had been provided by the university. Meanwhile, from the researcher's observation, currently the facilities required to support the utilization of e-learning at $\mathrm{X}$ University have been adequate. This phenomenon inevitably raises the question of how come not too many lecturers have used e-learning in their teaching and learning processes, be it the ones based on moodle or other e-learnings. Therefore, the researcher wishes to figure out several factors suspected to have some influence on the application of e-learning by accounting lecturers at X University.

One theory on the use of information technology system which can be used to explain an individual's acceptance to the use of information technology system is Technology Acceptance Model (TAM). TAM is a widely-used model in many studies on the process of adopting information technology. This model aims at explaining the main factors of user's behavior on acceptance of technology use. This model places the attitude factor of each user's behavior with two variables, namely ease of use and usefulness. These two aspects can explain user's behavioral aspect (Davis, et al,1989).

TAM model has been continuously developed by several researcher by adding some external variables which explain further or become antecedent of perceived use and ease to finish jobs or tasks at hand, as compared to those with fairly low anxiety. In addition to computer anxiety, demographic factors such as gender and age are also suspected to affect one's self-efficacy in using a computer. This is supported by the research conducted by He and Freeman (2009). Their research finds that women have higher self-inefficacy in using computer than men. Mini \& Janetius (2012) in their research results revealed that someone at older age is more likely to have higher resistance than those at younger age group since they are not too familiar with new technology.

Saade and Kira (2009) in their research results disclosed the direct relationship between computer anxiety and perceived ease of use. The research conducted by Sudaryono (2005) and Harimurti (2016) showed that computer anxiety has a negative effect on one's computer self- efficacy. On the other hand, Farokhah (2016) found the influence of computer self-efficacy on perceived ease of use of technology by someone. The lesser the anxiety that someone feels in using computer, the greater one's self-expertise in using computer, thus it can minimize their efforts in using new technology such as elearning. Thus, the researcher places computer self-efficacy as an intervening variable to show the indirect influence of computer anxiety on perceived ease of use of technology. This can be used as what makes this research different from previous studies. This research focuses on lecturers at a university since they are the main factor which can contribute to the success of a teaching and learning process (Al-Alak \& Alnawas, 2011) and their knowledge on technology and their attitude to technology play an important role in the use of e-learning technology.

\section{LITERATURE REVIEW AND HYPOTHESES}

Accepting or rejecting the existence of a new technology has been investigated in the field of information system. This investigation measures whether or not the technology is successful in the society. The use of available information technology has something to do with the behavior of individual who uses it. Jogiyanto (2007: 16) suggests that a model and theory is needed to explain the interaction between individuals and information system. One of the most commonly used theory in research on information technology is Technology Acceptance Model or TAM. This technology acceptance model is developed by Davis et al. (1989) based on Theory of Reasoned Action (TRA) model. TRA model can be applied since the decision made by individuals to accept an information system technology is a conscious action which can be explained and predicted by the behavioral intention.

Everyone has varied perception in viewing the development of information technology. Information technology changes the way people accomplish their daily problems and tasks. In a more detail, TAM model explains IT acceptance with certain dimensions which can influence whether or not IT is accepted by users. TAM model adds to main constructs into TRA model, namely perceived 
ease of use and perceived usefulness. TAM has 5 main constructs, namely: (1) Perceived usefulness, (2) Perceived ease of use, (3) Attitude toward using technology, (4) Behavioral intention to use, and (5) Actual technology use. The explanations of each construct above are as follows.

The first construct is perceived usefulness, hereinafter referred to as usefulness. Usefulness is defined as to what extent one believes that using a technology will improve their job performance (Davis, 1985: 26). This construct is influenced by the ease of use construct. Previous research indicated that usefulness is the most significant and important construct which influence attitude, intension and behavior (Jogiyanto, 2008: 114). There are 6 indicators to measure this usefulness construct, namely work more quickly, improve job performance, increase productivity, improve job effectiveness, makes job easier and useful (Davis, 1989).

The second construct is perceived ease of use, hereinafter referred to as ease of use. Ease of use is defined as to what extent people believe that using a technology will set them free from efforts (Davis, 1985: 25). This construct influence usefulness, attitude, intension and actual use of technology constructs. However, it has most significant influence on usefulness construct, and on other constructs it has insignificant influence (Jogiyanto, 2008: 115). There are 6 indicators to measure ease of use construct, namely the sistem's ease to be learned (easy of learn), the system's controllability (controllable), clear and understandable interaction with the system (clear and understandable), interaction flexibility (flexibility), easy to be skilled in using the system (easy to become skillful) and easy to use (Davis, 1989).

The third construct is attitude toward using technology, hereinafter referred to as attitude. Attitude can be defined as one's positive or negative feeling if they have to perform the behavior to be determined (Davis et al., 1989). In TAM model, attitude influences intension and is influenced by ease of use and usefulness. Jogiyanto (2008: 116) also suggests that in previously conducted studies, some of them showed that attitude has a positive influence on intension, yet some others indicated that attitude has no significant influence on intension. Therefore, some studies which employed TAM excluded the attitude construct from ther models. The fourth construct is behavioral intention to use, hereinafter referred to as intension. Intension influences actual use of technology and is influenced by attitude and usefulness. There are 2 indicators to measure the intension construct, namely using the system to complete the task (carrying out the task) and planned utilization in the future (Amoroso and Gardner, 2004). The fifth construct is actual technology use, hereinafter referred to as actual use of technology or simply use. In TAM, actual use of technology is equal to the term behavior in TRA, yet it is only to be used in technology context. This construct is directly influenced by intension and usefulness.

\section{Influence of Computer Anxiety on Perceived Ease of Use E-learning through Computer Self- Efficacy}

Computer anxiety is the anxiety in using computer and anxiety on the negative effect of computer use on the society (Emmons, 2003). The Social Cognitive Theory (Bandura, 1986, 1991; Wood \& Bandura, 1989) states that a behavior is the function of its consequence, it can be changed through cognitive mediation and social learning. The social cognitive theory shows that our self-arrangement mechanism can influence the relationship between our emotional passion and action or performance, and that this relationship is reciprocal. Thus, a change in one factor can lead to changes in other factors. The most important self-arrangement mechanism has been identified as self-efficacy which has been proved significantly influential on individual intension and behavior (De Vries, Backbier, Kok \& Dijkstra, 1995; Igbaria et al., 1994; Brubaker \& Fowler, 1990) and tightly related to anxiety (Harrison \& Rainer, 1992).

Based on the interpersonal behavior theory developed by Triandis (1980) in Jogiyanto (2007), it is stated that behavioral intensions (in this case technology acceptance) is highly influenced, among other things, by the feeling that an individual has. On the other hand, TAM theory which has been developed shows that self-efficacy influences perceived one's ease of use in using technology. Based on these theories, it can be then proposed that individuals with positive feeling towards computer use should have high capability in using the computer, hence it can result in their acceptance of a technology. When an 
individual has high confidence of their capability in using computer, it will not hard for them to use a new technology (perceived ease of use). This is supported by previous research conducted by Igbaria and Iivari (1995) which proved that computer self-efficacy had a direct effect on perceived ease of use.

Saade \& Kira (2009) had investigated the influence of computer anxiety on perceived ease of use as mediated by computer self-efficacy variable. In the first hypothesis, it was shown that computer anxiety had a direct influence on perceived ease of use. In the second hypothesis, after including computer selfefficacy as an intervening variable, the influence computer anxiety on perceived ease of use was lesser. Computer self-efficacy has a significant mediating influence to reduce anxiety of LMS use. Based on the explanation above, the following hypothesis is developed:

$\mathrm{H}_{1}=\quad$ Computer anxiety influences perceived ease of use of e-learning through computer self-efficacy.

\section{Influence of Age on Perceived Ease of Use through Computer Self-Efficacy}

Currently, the increasingly higher and more complicated work loads require lecturers to use computer as an aid to finish their jobs. As the job demands grow, an individual will attempt to improve their skills and abilities in using computer. Nevertheless, not every individual can easily accept or learn computer technology well, particularly in elder individuals. This is because they are more likely to have their ability to think decreased and less interested in learning a new technology.

Some researchers argued that more younger individuals used computer than their older counterparts. Thus, the lack of experience in using computer causes the performance of individual at older age lower than the younger ones (Dyck \& Smither, 1994). Sibona \& Choi (2012) had conducted a study on facebook user satisfaction. One of their findings was that users at older age saw the site more difficult to be used than younger users. Younger users might be more familiar with internet and IT than the older ones. Dyanrosi (2015) in his/her research also found that age had a negative significant influence on perceived ease of use. The path coefficient obtained from the research showed that the influence of age on perceived ease of use is inversely proportional, thus, the lower (younger) the age of an individual the greater their perceived ease of use would be.

Several years prior to these studies, Chung, et al (2010) had investigated the difference of age in perception of online community conducted by those who had participated in this community. The research used Technology Acceptance Model to investigate the factors influencing intension in the future to participate in online community. One of its findings revealed that age had no influence on perceived ease of use. In making decision whether to join or not in an online community, older adults were not necessarily more influenced by the ease of use in the online community than younger adults.

The different findings between Chung, et al (2010) and Sibona \& Choi (2012) and Dyanrosi (2015) make the researcher interested in placing computer self-efficacy as a mediating variable age and perceived ease of use of e-learning. Younger individuals will find it easier to use e-learning since they have the ability to use computer. Based on the explanation above, the following hypothesis is developed:

$\mathrm{H}_{2}=$ Age influences perceived ease of use of e-learning through computer self-efficacy.

\section{Influence of Gender on Perceived Ease of Use through Computer Self-Efficacy}

Etymologically, the word 'gender' comes from English which means 'sex'. Gender is an attribute which is used as the basis to identify the difference between male and female as seen from their sociocultucal condition. Several studies explained the importance of taking gender into consideration. Gefen and Straub (1997) explained that women had a positive influence on perceived usefulness, and men had a positive influence on perceived ease of use. Other researchers, i.e. Venkatesh and Morris (2000), tested the difference between women and men in the use of information technology. Their research found that women were more likely to use a technology under the influence of perceived ease of use and men were more likely to use a technology under the influence of perceived usefulness of that technology. Sanjaya (2008) suggested that gender positively influenced perceived usefulness and perceived ease of use.Another study found that gender had no influence on perceived ease of use, as the one conducted by Sari \& Baridwan (2012) and Dyanrosi (2015). This research result was 
consistent with what Harmadi and Hermana (2005) found in their research which analyzed the process of adoption in using information technology in a national private bank. Their research revealed that gender did not influence perceived ease of use to use technology-based information system.

Given the inconsistent research results above, it is reasonable to suspect that a factor might mediate the influence of gender on perceived ease of use. Some studies had shown the influence of one's gender difference on their expertise in using computer (computer self-efficacy), such as the ones conducted by Trisnaningsih (2004), Rustiana (2004), Tjandra (2007). Rustiana's (2004) research found that male students' CSE was better than the female ones. This was because men generally have higher ability to make innovations and conquer challenges.

Trisnaningsih (2004) in her research found generally held belief that men were more workoriented, objective, independent, aggresive, and had better abilities in general than women in terms of managerial responsibilities. On the other thand, women were deemed more passive, soft, consideration-oriented, more sensitive and had lower position in their accountability in an organization than men. Another finding also showed that sex had some influence on attitude towards computer. Harrison and Rainer (1992) found that male end user computing personnel had higher computer self-efficacy than women. An individual with high self-efficacy will find it easier to accept new technology than those with low computer self-efficacy. This statement is suppotted by the result of research conducted by Venkatesh and Davis (1996) and Hong et al. (2002). Based on the explanation above, the researcher formulates the following hypothesis:

$\mathrm{H}_{3}=$ Gender influences perceived ease of use of e-learning through computer self-efficacy.

\section{METHODS}

This research is explanatory research, i.e. testing the influence of independent variables on dependent variables which has been hypothesized. This research explains how computer anxiety, age, and gender influence perceived ease of use of e-learning through computer self-efficacy. The population in this research is all lecturers of accounting department at $\mathrm{X}$ university. The sample in this research is all lecturers of accounting department at X university, amounting to 32 lecturers. According to Arikunto (2006:134), if the research subject was less than 100, it is better to take them all as the sample, hence the research becomes population research.

Computer anxiety is an expression of negative feeling or exaggerated prejudice regarding difficulties caused by the utilization of computer which leads to antipathy to computer (Supriyadi, 2003). To measure students' anxiety level, the researcher used Computer Anxiety Rating Scale (CARS) instrument developed by Harrison and Rainer (1992). The respondents were asked to choose an answer to a question in the form of four-point interval scale. CARS instrument developed by Harrison \& Rainer showed that there were two items which indicated the existence of computer anxiety forming indicator. The first indicator shows that there is a computer fear, and the second indicator indicates that there is a computer anticipation or the feeling of being challenged in using computer. The respondent's age variable is known by asking the respondent to indicate their age in the questionnaire. Meanwhile, gender variable was measured using fixed response item ( $1=$ Man; $2=$ Woman).

The intervening variable in this research is Computer Self-Efficacy (Y). This computer self-efficacy by Indriantoro (2000) was defined as the computer user's efficacy in terms of computer application, computer operating system, file and hardware handlings, data storage and keyboard use. The term computer users means lecturers of accounting department at X University. Computer user's efficacy is measured using Computer Self-Efficacy Scale developed by Compeau \& Higgins (1995). Ease of use is defined as to what extent a person believes that using a technology will set them free from efforts (Davis, 1986). Perceived ease of use is part of TAM factors. 


\section{RESULTS}

Sub-structure 1 path analysis is used to discover the strength of relationship of independent variables (computer anxiety, age, and gender) on the mediating variable (computer self-efficacy).

Table 1. Relationship between independent variables and mediating variable

\begin{tabular}{|c|c|c|c|c|c|c|}
\hline & & \multicolumn{2}{|c|}{ Unstandardized } & \multirow{2}{*}{$\begin{array}{l}\text { Standardized } \\
\text { Coefficients }\end{array}$} & & \multirow[b]{3}{*}{ Sig. } \\
\hline & & \multicolumn{2}{|c|}{ Coefficients } & & & \\
\hline \multicolumn{2}{|c|}{ Model } & B & Std. Error & Beta & t & \\
\hline \multirow[t]{3}{*}{1} & (Constant) & 18.106 & 3.608 & & 5.018 & .000 \\
\hline & Computer_Anxiety_X1 & -.111 & .085 & .245 & -1.300 & .205 \\
\hline & Age_X2 & .004 & .048 & .018 & .091 & .929 \\
\hline & Gender_X3 & -.754 & 1.177 & -125 & .641 & 527 \\
\hline
\end{tabular}

From the table, it can be seen that computer anxiety, age and gender had sig value $>0.05$, meaning that the three variables had no influence on computer self-efficacy. Sub-structure 2 path analysis is used to discover the strength of relationship of independent variables (computer anxiety, age, gender, and computer self-efficacy) on the dependent variable (perceived ease of use of e-learning).

Table 2. Relationship between independent variables and dependent variable

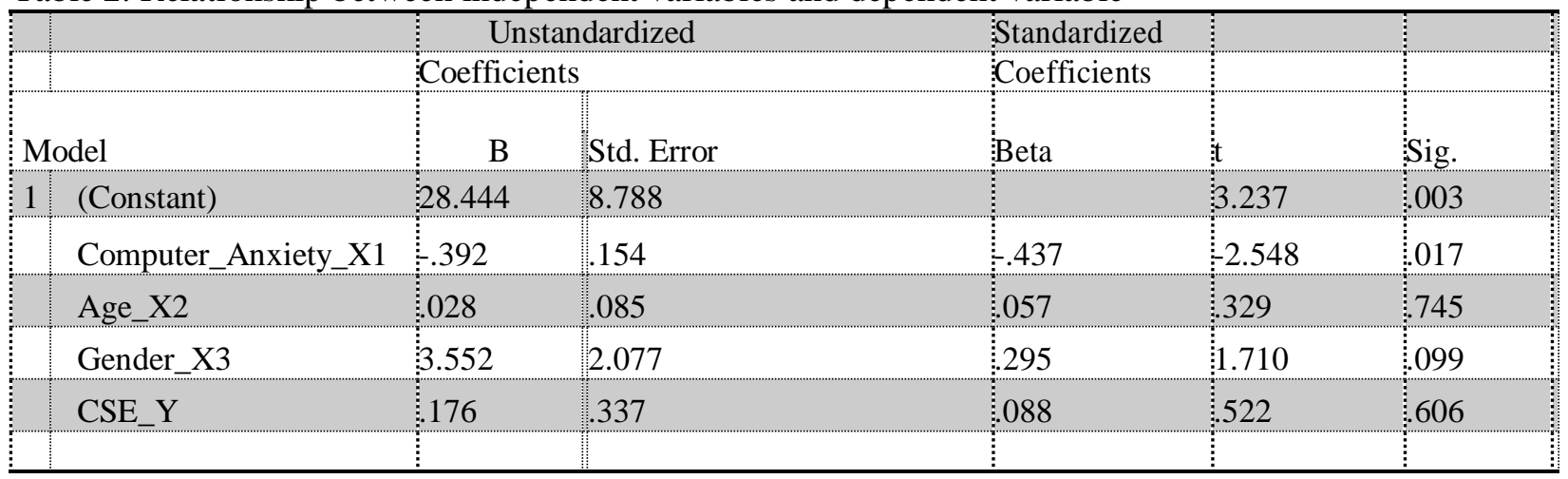

From the table, it can be seen that only computer anxiety influenced perceived ease of use of e-learning and neither age, gender nor computer self-efficacy had any influence on perceived ease of use of elearning. This was seen from the significance value which was greater than 0.05 .

\section{DISCUSSION}

Influence of computer anxiety on perceived ease of use of e-learning through computer self-efficacy.

In general, to acquire computer self-efficacy a user needs to be "computer literate". A computer iterate individual should feel comfortable using computer technology to solve their problems and finish their jobs (Holzinger, 1992). The rapid and dynamic change of technology may lessen one's confidence in learning and using new technology such as e-learning.

Based on Interpersonal Behavior Theory, one's attitude consists of such components as cognition, affect, and other behavior-related components. One's desire is influenced by believe and future consequence, thus it creates one's affect as expressed with like or dislike attitude towards computer technology. One's dislikeness to computer may be caused by fear of computer technology use or commonly known as computer anxiety (Igbaria and Pasuraman, 1989). Heinssen et al. (1987) research 
found that students with higher computer anxiety had lower belief on their own ability as well as lower performance than those with lower computer anxiety.

However, this research found that lecturers with low computer anxiety were not necessarily had higher computer self-efficacy. Most accounting lecturers at this X university had low computer anxiety, yet most of them also had low computer self efficacy. Thus, the result of this research did not confirm the many previously conducted studies, which found that an individual with low computer anxiety would have high computer self-efficacy.

Based on the previously developed TAM, the ease of use of technology is influenced, among other things, by computer self-efficacy. Their research had tested and analyzed the influence of Technology Acceptance Model (TAM) on land-related activity computerization. Their research found that computer self-efficacy significantly influenced perceived ease of use. This phenomenon was possible since employees had high confidence in their ability and skill in using land-related activity computerization application. Therefore, they found it easy to use the application with no need for great efforts.

This research result did not support Handayani and Harsono's finding (2016). This research showed that computer self-efficacy had no significant influence on perceived ease of use. This meant that the respondents thought that their ability in operating computer did not affect the ease of e-learning application. New technologies such as internet use, either for e-learning or other purposes have been closest part of human life. Nowadays, e-learning has been an independent technology where its users can use media other than computer to access it. This led to the respondents' belief that computer self-efficacy had no influence on perceived ease of use of e-learning. This research confiemd the study conducted by Nurhayati (2011).

This research also showed the direct influence of computer anxiety on perceived ease of use of elearning. The standardized coefficients value indicated a negative number, meaning that computer anxiety negatively influenced perceived ease of use of e-learning. The lower an individual's anxiety in using computer, the higher their perceived ease of use in using e-learning. This result was supported by the research conducted by Saade \& Kira (2009) which found the negative effect of computer anxiety on perceived ease of use.

Computer self-efficacy (Y) in this research did not mediate the relationship between computer anxiety and perceived ease of use (Z). This was indicated by the value of indirect influence between computer anxiety on perceived ease of use through computer self-efficacy whose value was less than the direct influence of computer anxiety on perceived ease of use.This research did not support Saade and Kira's (2009) research, where it was found that computer self-efficacy had a significant mediating influence to lessen anxiety of LMS (Learning Management System) utilization.

\section{Influence of age on perceived ease of use of e-learning through computer self-efficacy}

Based on XYZ Generation Theory, most accounting lecturers at X University were included into X and Y generations. The X generation was those born in 1965 to 1980 . The years when those from this generation were born were the beginning of PC (personal computer) use, video games, cable tv, and the internet. The Y generation was born in 1981 to 1994. This generation used instant communication technologies such as email, SMS, instant messaging and social media such facebook and twitter. Referring to this generation theory, it could be said that lecturers in younger generation were inevitably more familiar with technology advancement, particularly in terms of computer use. This had been proven by the research conducted by Jum'ati and Ismoyo (2014), where older respondents showed lower computer self-efficacy.

Unlike this thought, this research showed that respondent's age had no influence on computer selfefficacy. The advancement of technology had benefited every individual from various ages. Thus, computer self-efficacy was not just owned only by lecturers at a certain age range. Not every individual at younger age had higher computer self-efficacy. This research result was supported by Unlu and Suel's (2014) research which found that there was no significant relationship between age and computer selfefficacy. 
The technology advancement had demanded people to keep on learning new technologies and this applied to both younger and older lecturers. Lecturers should be capable of using both computer and the internet to develop their teaching methods. Therefore, age was not an obstacle for them to learn and use elearning as a teaching and learning method. The result of analysis using SPSS in chapter IV revealed that respondents' age did not directly influence perceived ease of use of e-learning. This result was also supported by the research conducted by Chung, et al (2010) who found that age did not affect perceived ease of use. Based on the multiplication result, it was found that age had no influence on the perceived ease of use variable. This was proven by the greater value of direct influence coefficient of age on perceived ease of use than the indirect influence through computer self-efficacy variable.

\section{Influence of gender on perceived ease of use of e-learning through computer self-efficacy.}

Gender is one factor necessary to be investigated in relation to technology application. The theories from psychology and sociology fields suggested that gender difference in competence and use of information technology (the internet) occurred due to the sex-based role formation (Mira, 1987). For example, when the society associates computer with man characteristics, then woman will avoide information technology. This leads to woman's disadvantage in the field. Rustiana (2004) proved that men's ability in computer was better than women. This was because men generally had higher ability and willingness to make innovations and conquer challenges. Based on the analysis in Chapter IV, it was found that the self-confidence of accounting lecturers at X University in using computer was not influence by gender. This research confirmed the study conducted by Unlu and Suel (2014).

This research showed the absence of direct influence of gender on perceived ease of use of e-learning. Thus, the gender difference hypothesis which believed that men had better ability in information technology acceptance was not proven. This result supported the hypothesis or theory on demolishing gender stereotype which believed that currently the gender characteristics embedded to men and women were nearly the same, particularly in relation to information technology. The statement was made based on the fact that women were more likely to emulate men in terms of characteristics and capability at work. This testing result added another inconsistency with previous studies' results which obtained varied findings.

This research confirmed the study conducted by Belle, et al (2005). Their research revealed the insignificant relationship in perceived ease of use of technology between men and women. Computer selfefficacy $(\mathrm{Y})$ in this research did not successfully mediate the relationship between gender $\left(\mathrm{X}_{3}\right)$ and perceived ease of use (Z). This statement was indicated by the value of indirect influence of gender on perceived ease of use through computer self-efficacy whose value was less than the direct influence of gender on perceived ease of use.

\section{CONCLUSION}

This research results indicated that, firstly, no significant influence was found of computer anxiety on perceived ease of use through computer self-efficacy; secondly, no significant influence was found of respondents' age on perceived ease of use through computer self-efficacy, thirdly; no significant influence was found of gender on perceived ease of use through computer self-efficacy. Additionally, accounting lecturers at $\mathrm{X}$ university should improve their ability in computer, particularly those lecturer with low computer self-efficacy, since this research indicated that some lecturers still had low self-confidence in using computer, i.e. at a percentage of $42 \%$. If they do just that then it will be helpful considering the increasingly rapid development of technology in education.

\section{REFERENCES}

A-Alak B.A \& Alnawas I.A.M. 2011. Measuring the Acceptance and Addoption of E-Learning by Academic Staff. Knowledge Management \& E-Learning: An International Journal, 3(2)

Arikunto, Suharsimi. 2006. Prosedur Penelitian: Suatu Pendekatan Praktik. Jakarta: Bumi aksara 
Bandura, A. 1982. Self-Efficacy Mechanism in Human Agency. American Psychologist, 37(2):122-147

Compeau, D. R., Higgins, C. A. 1995. Computer Self-Efficacy: Development of a Measure and Initial Test. MIS Quarterly, 19 (2): 189-211

Davis, F. D., Bagozzi, R. P., \& Warshaw, P. R. 1989. User Acceptance of Computer Technology: A Comparison of Two Theoretical Models. Management Science, 35 (8): 982-1003

De Vries et al. 1995. The Impact of Social Influences in the Context of Attitude, Self-Efficacy, Intention, and Previous Behavior as Predictors of Smoking Onset. Journal of Apllied Social Psychology, 25 (3): $237-257$

Dyanrosi, Aulia. 2015. Analisis Perilaku Wajib Pajak Orang Pribadi terhadap Minat Perilaku Menggunakan E-Filing. Jurnal Ilmu Sosial dan Ilmu Politik. 4 (2)

Dyck, J.L., Smither, J.A. 1994. Age Differences in Computer Anxiety: The Role of Computer Experience, Gender and Education. Journal of Educational Computing Research, 10 (3).

Emmons, B.A. 2003. Computer Anxiety, Communication Preferences, and Personality Type in the North Carolina Cooperative Extension Service. Disertasi tidak dipublikasikan, North Carolina State University

Gefen, D. \& Straub, D. 1997. Gender Difference in the Perception and Use of EMail: An Extension to the Technology Acceptance Model. MIS Quarterly, 21 (4): 389-400.

Harrison, A.W. dan Rainer, K.R. 1992. The Influence of Individual Differences on Skill in End-User Computing. Journal of Management Information System, Summer 9 (1): 93-111.

He, Jun \& Freeman, Lee, A. 2009. Are Men More Technology-Oriented Than Woman? The Role of Gender on the Development of General Computer Self-Efficacy of College Students. Journal of Information System Education, 21 (2): 203-212

Hong W, J.Y.L. Thong, W.M. Wong dan K.Y. Tam. 2002 . Determinants of User Acceptance of Digital Libraries: An Empirical Exaniation of Individual Differences and System Characteristics. Journal of Management Information System, 18 (3) : 97-124

Igbaria, M dan Parasuraman, S., 1989. A Path Analytic Study of Individual Characteristics, Computer Anxiety, and Attitudes Toward Microcomputer. Jurnal of Management, 15 (3).

Igbaria, M., dan J. Iivari. 1995 .The Effect of Self Efficacy on Computer Usage. Omega, 23 (6): 587-605

Jogiyanto. 2007. Sistem Informasi Keperilakuan - Edisi Revisi. Yogyakarta: Penerbit Andi

Jum'ati, N dan Iswoyo, A. 2014. The Influence of Demography and Computer Anxiety Factors to CSE Survey on Village Officials of Benjeng District in Gresik Residence. European Journal of Computer Science and Information Technology, 2 (3): 17-35

Mini \& Janetius, T,C. 2012. Technology Adaptation, Innovation Resistance and Net-Banking Behavior among Middle Aged Adults. IOSR Journal of Business and Management,. 3 (1): 1-5.

Rustiana. 2004. Computer Self-Efficacy (CSE) Mahasiswa Akuntansi dalam Penggunaan Teknologi Informasi: Tinjauan Perspektif Gender. Jurnal Akuntansi dan Keuangan, 6 (1): 29-39.

Saade, R.,G.\& Kira, Dennis. 2009. Computer Anxiety in E-Learning: The Effect of Computer SelfEfficacy. Journal of Information Technology Education. Vol.8:177-191

Sanjaya Sugiartha. 2008. Analisis Pengaruh Sikap Komputer dan Kegunaan Persepsian terhadap Minat Perilaku yang Dimoderasi oleh Perbedaan Gender. Jurnal Manajemen Teori dan Terapan, 1 (1). 
Sari, M. W., Baridwan, Zaki. 2012. Sikap Penggunaan Mobile Commerce: Modifikasi Teori Technology Acceptance Model. Jurnal Ilmiah Mahasiswa FEB Universitas Brawijaya, 1 (2): 121.

Sudaryono, E. A., Astuti, I. D. 2005. Pengaruh Computer Anxiety Terhadap Keahlian Karyawan Bagian Akuntansi dalam Menggunakan Komputer: Survai pada Perusahaan Tekstil di Surakarta. Jurnal Akuntansi Dan Keuangan, September, 5 (1): 894-902

Supriyadi. 2003. Pengaruh Persepsi Kemudahan, Persepsi Kemanfaatan,Kecemasan, Siakp dan Penggunaan Komputer terhadap Kinerja dan Kepuasan Kerja Akuntan Pendidik. Tesis. Universitas Diponegoro Semarang.

Tjandra, Ronowati. 2007. Computer Anxiety dari Perspektif Gender dan Pengaruhnya Terhadap Keahlian Pemakai Komputer dengan Variabel Moderasi Locus of Control. Tesis tidak diterbitkan. Universitas Diponegoro Semarang.

Trisnaningsih, Sri. 2011. Faktor-faktor yang Mempengaruhi Kinerja Dosen Akuntansi. Jurnal Akuntansi dan Auditing, 8 (1): 1-94

Unlu, Huseyin dan Suel, Emin. 2014. Computer Self-Efficacy of Prospective Physical Education Teachers. Journal on Efficiency and Responsibility in Education and Science, 7 (2): 33-36.

Van Belle, J.P. \& Stander, A. 2005. Gender Differences in The Perception and Use of E-Mail in Two South African Organisations. The Electronic Journal of Communication, 15(1\&2): 131-142.

Venkatesh, V. dan Michael G. Morris. 2000. Why Don't Men Ever Stop to Ask for Direction? Gender Social Influence, and Their Role in Technology Acceptence and Usage Behavior. MIS Quarterly, 24 (1): 115-139 